\title{
Correlation of Symptoms with Intravitam Confirmed Rabid Cases by Molecular Approaches
}

\author{
K Bansal $^{1}$, C K Singh ${ }^{1}$, M Dandale ${ }^{1}$, B S Sandhu ${ }^{1}$ and N K Sood ${ }^{1}$ \\ ${ }^{1}$ Department of Veterinary Pathology, College of Veterinary Sciences, Guru Angad Dev Veterinary and Animal \\ Sciences University, Ludhiana-141004, India
}

\begin{abstract}
For the productive application of molecular approaches for detection of rabies in live animals in the field conditions, the detection of rabies by TaqMan real time PCR and Nested RT-PCR was correlated with the observation of clinical symptoms in the suspected animals. TaqMan real time PCR and Nested RT-PCR applied on skin samples of 20 animals have confirmed rabies viral RNA in 11 and 9 cases, respectively. Out of 11 TaqMan confirmed rabies positive cases early phase symptoms off feed, fever and behavioural change was exhibited by 8, 6 and 3 animals, respectively with a sensitivity of $84.61 \%, 68.75 \%$ and $57.89 \%$. Out of 9 Nested $R T$-PCR confirmed cases off feed, fever and behavioural changes was present in 8,5 and 2 cases, respectively with a sensitivity of $90 \%, 69.23 \%$ and $56.25 \%$. Mid phase symptoms micturition and bellowing was present in 2 and 5 out of 11 TaqMan and 9 Nested confirmed cases. Late phase symptoms like difficulty in standing walking and difficulty intake, Salivation and paralysis was observed in 3, 3, 8 and 1 out of 11 TaqMan confirmed cases with a sensitivity of $57.89 \% 57.89 \%, 78.57 \%$ and $52.38 \%$ respectively and 3, 3, 6, 1 out of 9 Nested PCR confirmed cases with a sensitivity of $60 \%, 60 \%, 52.94 \%$ and $75 \%$.
\end{abstract}

Keywords: Intravitam, clinical signs, correlation, molecular diagnosis, rabies

\section{INTRODUCTION}

Rabies is fatal, viral zoonotic disease caused by rabies virus which belongs to genus Lyssavirus of the family Rhabdoviridae. India has the dubious distinction among the rabies enzootic Asian countries in reporting more than 20000 human rabies deaths annually [1]. About 17.4 million Indians are exposed to rabies every year and require post exposure prophylaxis treatment which costs around \$25 millions [2].

Rabies has major public health implications and it is important for the veterinarian to be able to recognize the disease as early as possible, to minimize human contact and for timely administration of post exposure prophylaxis. Lack of early recognition of an impending rabies epidemic can result in wider spread, human deaths and great difficulties in controlling the disease [3].

The Intravitam diagnosis of rabies is possible on the basis of the case history and the careful observation of clinical signs [4]. Intravitam diagnosis has also been successfully reported by use of molecular approaches on saliva, skin, urine and CSF samples. Since, a systematic correlation of clinical signs with molecular approaches for Intravitam diagnosis of rabies in animals has been neglected by the literature. So the present study was conducted with an aim to correlate the presence of specific clinical signs in animal that were confirmed rabies positive by applying Intravitam molecular approach viz. Taqman real time PCR and Nested RT-PCR on skin samples.

\subsection{Clinical signs}

\section{MATERIALS AND METHODS}

History (species, sex, age) and various clinical signs and symptoms were recorded of 20 animals suspected to be rabid presented to the Veterinary Clinics, GADVASU, Ludhiana, Punjab and Civil Veterinary Hospital from different districts of Punjab. Signs and symptoms included in study were divided into three stages; mainly early phase characterized by off feed, fever, behavioural change, mid phase characterized by bellowing and micturition and late phase characterized by salivation, difficult intake, difficult standing and walking and paralysis.

\subsection{Collection of samples}

Skin biopsies (with a minimum of 10 hair follicles) with the help of sterilized skin biopsy punch were collected from all animals.

\subsection{RNA extraction and cDNA synthesis}

Total RNA from skin samples, positive and negative controls was extracted using Qiazol (Qiagen, USA) according to the manufacturer's instructions. The RNA was subjected to cDNA synthesis using a primer RabN1 ( $30 \mathrm{pmol} / \mu \mathrm{l})$ and subjected to $65^{\circ} \mathrm{C}$ for $10 \mathrm{~min}$ and was later snap cooled on ice and briefly spun down. 
Correlation of Symptoms with Intravitam Confirmed Rabid Cases by Molecular Approaches

cDNA synthesis was done using high-capacity cDNA reverse transcription kit (Applied Biosystems, USA). Reverse transcriptase (Applied Biosystems, USA) mix was prepared and subjected to conditions $25^{\circ} \mathrm{C}$ for 10 $\min , 37^{\circ} \mathrm{C}$ for $2 \mathrm{~h}, 85^{\circ} \mathrm{C}$ for $5 \mathrm{~min}$ and chilling on ice for $5 \mathrm{~min}$ in a thermal cycler (Eppendorf).

\subsection{Nucleic acid analysis}

RNA and cDNA concentration was measured using Nano Drop Spectrophotometer (Nanodrop Technologies, CA) in $n g / \mu l$ and quality was checked as a ratio of OD 260/280.

\section{$2.5 \quad$ Nested RT-PCR assay}

The procedure used for the nested RT-PCR was that used earlier $[5,6,7]$ with minor modifications. Briefly, $12 \mu \mathrm{l}$ of cDNA was subjected to a first round amplification using RabN1 and RabN5 primers (30 $\mathrm{pmol} / \mu \mathrm{l}$ ), dNTP's and Taq DNA polymerase for $95^{\circ} \mathrm{C}$ for 2 min followed by 35 cycles of $95^{\circ} \mathrm{C}$ for $1 \mathrm{~min}, 55^{\circ} \mathrm{C}$ for $1 \mathrm{~min}, 72^{\circ} \mathrm{C}$ for $1 \mathrm{~min} 30 \mathrm{~s}$ and a final extension step at $72^{\circ} \mathrm{C}$ for $5 \mathrm{~min}$. For the second round, $5 \mu \mathrm{l}$ of first round PCR product was amplified using nested set of primers Rab Nfor and Rab Nrev and subjected to initial denaturation at $95^{\circ} \mathrm{C}$ for $2 \mathrm{~min}$ followed by 35 cycles of $95^{\circ} \mathrm{C}$ for $1 \mathrm{~min} 50^{\circ} \mathrm{C}$ for $1 \mathrm{~min}, 72^{\circ} \mathrm{C}$ for $1 \mathrm{~min}$ and a final extension step at $72{ }^{\circ} \mathrm{C}$ for $5 \mathrm{~min}$. The amplified PCR products were loaded on agarose gels along with positive control, negative control and DNA ladder (100 base pair plus, Fermentas). The agarose gels were visualized under Geldoc (Bio-Rad) and photographed with the same software.

\subsection{TaqMan real time PCR assay}

The TaqMan real time assay was standardized and carried out in $25 \mu \mathrm{l} \mathrm{PCR} \mathrm{mixture} \mathrm{volume} \mathrm{consisting}$ of $12.5 \mu \mathrm{l}$ of TaqMan master mix (Applied Biosystems, USA) with $2.5 \mu \mathrm{l}$ of primers Rab-8F and Rab-8R $(400 \mathrm{~nm} / \mu \mathrm{l})$ and $1 \mu \mathrm{l}$ probe $\operatorname{Rab}-8 \operatorname{Pr}(250 \mathrm{~nm} / \mu \mathrm{l})$ and $5 \mu \mathrm{l}$ of the cDNA prepared using RabN1 primer. Amplification was carried out at $50^{\circ} \mathrm{C}$ for $2 \mathrm{~min}, 95^{\circ} \mathrm{C}$ for $10 \mathrm{~min}$, followed by 40 cycles in two steps: $95^{\circ} \mathrm{C}$ for $15 \mathrm{~s}, 60^{\circ} \mathrm{C}$ for $1 \mathrm{~min}$. Amplification, data acquisition and analysis were carried out by using ABI 7500 instrument and ABI prism SDS software which determines the cycle threshold $(\mathrm{Ct})$ that represents the number of cycles in which the fluorescence intensity is significantly arose above the background fluorescence.

\subsection{Statistical Analysis}

Sensitivity of various clinical symptoms recorded was calculated in comparison with confirmed true positive rabies cases by application Nested RT PCR and TaqMan real time PCR on skin samples.

The sensitivity of various clinical symptoms recorded was calculated using formulae:

Sensitivity $=\frac{\text { True positive }}{\text { True positive }+ \text { False negative }} \times 100$

\subsection{Clinical detail of animals}

III. RESULTS

20 animals comprising of 7 buffaloes (all females), 5 cows ( 4 females, 1 male) and 8 dogs ( 3 female, 5 males) were incorporated in the present study. Mean average age of buffaloes was $5.57 \mathrm{yrs}$ (range $2 \mathrm{yrs}-8 \mathrm{yrs}$ ), while mean average age of cows was 1.81 yrs (range 1 month -4.5 yrs) and mean average age of dogs was 4.10 yrs (range 3.5 month - 12 yrs).

\subsection{Analysis of Nucleic acid}

The 260/280 ratio of RNA was in the range of 1.70-1.89 while the concentration varied from 100.17$744.40 \mathrm{ng} / \mu \mathrm{l}$ and the $260 / 280$ ratio of cDNA was in the range of 1.87-2.12 and concentration varied from $2021.80-4708.40 \mathrm{ng} / \mu \mathrm{l}$.

\subsection{Correlation of TaqMan real time PCR positive cases with clinical cases}

By application of TaqMan real time PCR assay viral RNA could be diagnosed in 11/20 skin samples. In TaqMan real time PCR, confirmed positive cases the presence of early phase symptoms viz. Off feed sign was exhibited by $9 / 11(81.81 \%)$ cases with a sensitivity of $84.61 \%$, while fever was present in $6 / 11(54.54 \%)$ cases with a sensitivity of $68.75 \%$. Behavioral change was observed in $3 / 11(27.27 \%)$ cases with a sensitivity of $57.89 \%$.

Mid phase symptoms micturition was present in lower number 2/11(18.18\%) cases with a sensitivity of $55 \%$ while bellowing sign was shown by $5 / 11(45.45 \%)$ cases, with a sensitivity of $64.70 \%$.

Late phase symptoms like difficulty in standing walking and difficulty intake was observed in $3 / 11$ (27.27\%) cases with a sensitivity of $57.89 \%$, while paralysis was observed in $1 / 13(9.09 \%)$ cases with a 
Correlation of Symptoms with Intravitam Confirmed Rabid Cases by Molecular Approaches sensitivity of $52.38 \%$. Salivation was observed in higher number 8/11 (72.72\%) of cases with a sensitivity of $78.57 \%$.

\subsection{Correlation of Nested RT-PCR positive cases with clinical cases}

Nested RT-PCR assay was able to diagnose rabies viral RNA in 9/20 skin samples. In, Nested RT-PCR confirmed positive cases the presence of early phase symptoms viz. Off feed sign was exhibited by $8 / 9(88.88 \%)$ cases with a sensitivity of $90 \%$, while fever was present in $5 / 9(55.55 \%)$ cases with a sensitivity of $69.23 \%$. Behavioral change was observed in $2 / 9(22.22 \%)$ cases with a sensitivity of $56.25 \%$.

Mid phase symptoms micturition was present in $2 / 9(22.22 \%)$ with a sensitivity of $56.25 \%$ while bellowing sign was shown by $5 / 9(55.55 \%)$ cases, with a sensitivity of $69.23 \%$.

Late phase symptoms like difficulty in standing walking and difficulty intake was observed in 3/9 (33.33\%) cases with a sensitivity of $60 \%$, while paralysis was observed in $1 / 9(11.11 \%)$ cases with a sensitivity of $52.94 \%$. salivation was observed in higher number $6 / 9$ (66.67\%) of cases with a sensitivity of $75 \%$.

\section{Discussion}

For the productive application of molecular approaches for detection of rabies in live animals in the field conditions, the detection of rabies by TaqMan real time PCR and Nested RT-PCR was correlated with the observation of clinical symptoms in the suspected animals, since it is of paramount importance to establish the stage of disease progression viz. a viz. clinical syndrome, so that a correlation may be built for logical feasibility of employing molecular approaches for detection of rabies in live animals.

Sign of early phase namely off feed was observed in most of TaqMan real time PCR and Nested RTPCR confirmed cases. The presence of behavioral change was observed in less number of cases in contrast to findings of another study [8] which reported aggressive behavior in $77 \%$ of rabid dogs. While late phase sign, salivation was second most observed clinical sign observed in animals. However other study revealed presence late phase symptoms was the most common clinical picture in cattle [9].

Mid phase symptom were observed in equal number of TaqMan real time PCR and Nested RT-PCR confirmed cases however, the sensitivity of diagnosis on the basis of mid phase was more with Nested RT-PCR technique than TaqMan real time PCR.

Late phase sign, salivation was observed in higher number of cases that were confirmed positive with both techniques. Paralysis was observed only in 1 case.

The perusal of literature reveals that the information regarding correlation of clinical syndromes with molecular approaches for detection of rabies in animals is lacking.

\section{CONCLUSION}

It was concluded that in absence of symptoms namely off feed, fever, salivation and bellowing chances of false negative ante-mortem result by molecular approach increase. In other words, molecular ante-mortem detection should be attempted preferably in those animals that reveal off feed, fever, salivation and frequent bellowing. Since this is an early analysis based on a few cases, therefore, further studies are recommended.

\section{ACKNOWLEDGEMENTS}

Authors are grateful to Dr. S N S Randhawa, Director of Research, GADVASU for providing the necessary research facilities and Director Animal Husbandry for sponsoring research scheme entitled "Development of Research-cum-Diagnostic laboratory for Rabies".

\begin{tabular}{|c|c|c|c|c|c|c|c|c|c|c|c|c|c|c|}
\hline \multirow{3}{*}{$\begin{array}{l}\text { S. } \\
\text { No } \\
\text { • }\end{array}$} & \multirow{3}{*}{$\begin{array}{c}\text { Speci } \\
\text { es }\end{array}$} & \multirow{3}{*}{$\begin{array}{l}\text { Se } \\
x\end{array}$} & \multirow{3}{*}{$\begin{array}{l}\text { A } \\
\text { G } \\
\text { E }\end{array}$} & \multicolumn{9}{|c|}{ Clinical signs } & \multirow{3}{*}{\begin{tabular}{l} 
TaqM \\
an \\
Real \\
time \\
\multicolumn{1}{|c|}{ Skin }
\end{tabular}} & \multirow{3}{*}{$\begin{array}{l}\text { Neste } \\
\text { d } \\
\text { RT- } \\
\text { PCR } \\
\text { Skin }\end{array}$} \\
\hline & & & & \multicolumn{3}{|c|}{ Early phase } & \multicolumn{2}{|c|}{$\begin{array}{c}\text { Mid } \\
\text { phase }\end{array}$} & \multicolumn{4}{|c|}{ Late phase } & & \\
\hline & & & & $\begin{array}{r}\text { Off } \\
\text { feed }\end{array}$ & $\begin{array}{l}\text { Be } \\
\text { ha } \\
\text { vio } \\
\text { ur } \\
\end{array}$ & $\begin{array}{l}\text { F } \\
\text { ev } \\
\text { er }\end{array}$ & $\begin{array}{l}\text { M } \\
\text { ic } \\
\text { tu } \\
\text { ri }\end{array}$ & $\begin{array}{l}\text { Bel } \\
\text { lo- } \\
\text { wi } \\
\text { ng }\end{array}$ & $\begin{array}{c}\text { Diffic } \\
\text { ulty } \\
\text { in } \\
\text { stand }\end{array}$ & $\begin{array}{c}\text { Sali } \\
\text { vati } \\
\text { on }\end{array}$ & $\begin{array}{l}D \\
\text { if } \\
\text { fi } \\
- \\
\end{array}$ & $\begin{array}{l}\text { Par } \\
\text { alys } \\
\text { is }\end{array}$ & & \\
\hline 1 & Buffal & $\mathrm{F}$ & 2 & + & - & + & - & + & - & - & + & - & + & + \\
\hline 2 & Cow & M & $3 \mathrm{y}$ & + & - & + & - & + & + & + & - & - & + & + \\
\hline 3 & Buffal & $\mathrm{F}$ & 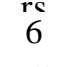 & + & - & - & + & + & - & + & - & - & + & + \\
\hline 4 & Cow & $\mathrm{F}$ & irrc & + & - & + & - & - & - & + & - & - & + & + \\
\hline 5 & $\begin{array}{l}\text { Calf } \\
\text { Dog }\end{array}$ & $\mathrm{F}$ & $\begin{array}{l}\mathrm{mt} \\
2.5 \\
\mathrm{vrc}\end{array}$ & + & + & + & - & - & - & + & + & - & + & + \\
\hline
\end{tabular}


Correlation of Symptoms with Intravitam Confirmed Rabid Cases by Molecular Approaches

\begin{tabular}{|c|c|c|c|c|c|c|c|c|c|c|c|c|c|c|}
\hline 6 & Cow & $\mathrm{F}$ & 1 & + & - & + & - & - & - & + & - & - & + & - \\
\hline 7 & $\begin{array}{l}\text { calf } \\
\text { Dog }\end{array}$ & $\mathrm{M}$ & $\begin{array}{l}\mathrm{mt} \\
12\end{array}$ & - & + & - & - & - & - & + & - & - & + & - \\
\hline 8 & Dog & M & $\begin{array}{l}\text { vrc } \\
1 y\end{array}$ & + & + & + & - & - & + & + & - & + & + & + \\
\hline 9 & Dog & M & 7.5 & - & - & - & - & - & - & - & - & - & + & + \\
\hline 1 & Buffal & $\mathrm{F}$ & $\stackrel{\text { vrc }}{6}$ & + & - & - & + & + & - & + & + & - & + & + \\
\hline$\stackrel{0}{1}$ & Cow & $\mathrm{F}$ & $\begin{array}{c}\mathrm{vrc} \\
1\end{array}$ & + & - & - & - & + & + & - & - & - & + & + \\
\hline & & & Tot & 9/11 & $3 / 11$ & $6 / 1$ & $2 / 1$ & $5 / 11$ & $3 / 11$ & $8 / 1$ & $3 / 11$ & $1 / 11$ & 11/11 & 9/11 \\
\hline
\end{tabular}

Table 1: Details of Clinical Signs Present in Animals

Table 2: Clinical Symptoms of Animals Confirmed Rabid by Taqman Real Time PCR

\begin{tabular}{|c|c|c|c|}
\hline $\begin{array}{l}\text { S. } \\
\text { No. }\end{array}$ & Clinical symptoms & $\begin{array}{l}\text { TaqMan +ve cases } \\
\text { Skin (11) }\end{array}$ & $\%$ Sensitivity \\
\hline 1. & Off feed & 9 & 84.61 \\
\hline 2. & Behavioural change & Early & 57.89 \\
\hline 3. & Fever & phase & 68.75 \\
\hline 4. & Micturition & Mid & 55.0 \\
\hline 5. & Bellowing & phase & 64.70 \\
\hline 6. & Difficulty in standing walking & 3 & 57.89 \\
\hline 7. & Difficult intake & Lat & 57.89 \\
\hline 8. & Salivation & phase & 78.57 \\
\hline 9. & Paralysis & . & 52.38 \\
\hline
\end{tabular}

Table 3: Clinical Symptoms of Animals Confirmed Rabid by Nested RT-PCR

\begin{tabular}{|c|c|c|c|}
\hline $\begin{array}{l}\text { S. } \\
\text { No. }\end{array}$ & Clinical symptoms & $\begin{array}{c}\text { Nested +ve cases } \\
\text { Skin (9) } \\
\end{array}$ & $\%$ Sensitivity \\
\hline 1. & Off feed & 8 & 90.0 \\
\hline 2. & Behavioural change & 2 & 56.25 \\
\hline 3. & Fever & Early & 69.23 \\
\hline 4. & Micturition & phase & 56.25 \\
\hline 5. & Bellowing & & 69.23 \\
\hline 6. & Difficulty in standing walking & hase & 60.0 \\
\hline 7. & Difficult intake & phase & 60.0 \\
\hline 8. & Salivation & - & 75.0 \\
\hline 9. & Paralysis & 1 & 52.94 \\
\hline
\end{tabular}

\section{REFERENCES}

[1] T. Nagarajan, S. B. Nagendrakumar, B. Mohannasubramanian, S. Rajalakshmi, N. R. Hanumantha, R. Ramya, D. Thiagarajan and V. A. Srinivasan, Phylogenetic analysis of nucleoprotein gene of dog rabies virus isolates from Southern India, Infectious Gene Evolution, 9, 2009, 976-982.

[2] R. Menezes, Rabies in India, Canadian Medical Association, 178(5), 2008, 564-566.

[3] C. Windiyaningsih, H. Wilde, F. X. Meslin, T. Suroso and H. S. Widarso. The rabies epidemic on Flores Island, Indonesia $1998-2003$. Journal of Medical Association Thailand, 87, 2004, 1389-93.

[4] D. B. Fishbein, J. S. Smith, C. E. Rupprecht and K. Clark. Unexplained rabies in three immigrants in the United States. A virologic investigation. N. Engl. J. Med., 324, 1991, 205-11.

[5] S. A. Nadin-Davis, Polymerase chain reaction protocols for rabies virus discrimination. Journal of Virological Methods, 75, $1998,1-8$.

[6] A. Kaw, C. K. Singh, B. S. Sandhu, N. K. Sood, Ramneek, D. Deka and S. Awahan, Diagnosis of rabies in animals by Nested RTPCR, Indian Journal of Animal Sciences, 81(4), 2011, 367-369.

[7] T. Nagaraj, P. V. Joel, A. Desai, A. Kamat, S. N. Madhusudana and V. Ravi. Ante mortem diagnosis of human rabies using saliva samples: Comparison of real time and conventional RT-PCR techniques, Journal of Clinical Virology, 36, $2006,17-23$.

[8] L. H. Q. Silva, C. E. Bissoto, A. C. B. Delbem, CI. De. L. Ferrari, S. H. V. Perri, C. M. de-L. Nunes, C. I. Ferrari and L. H. Q. daSilva, Canine rabies epidemiology in Aracatuba and neighborhood, Northwestern Sao Paulo State Brazil, Revista-da-SociedadeBrasileira-de-Medicina-Tropical, 37, 2004, 139-42.

[9] P. M. O. Pedroso, E. M. Colodel, C. A. Pescador, L. P. Arrudo and D. Driemeier, Clinical and pathological aspects in cattle affected by rabies with special reference to the rabies antigen mapping by immunohistochemistry. Pesquisa Veterinaria Brasileira., 29(11), 2009, 899-904. 